\title{
CHARACTERIZATION OF COFFEE CULTIVARS LEAF RUST-RESISTANT SUBJECTED TO FRAMEWORK PRUNING
}

\author{
Estevam Antônio Chagas Reis ${ }^{1}$, Tainah Freitas ${ }^{2}$, Milene Alves de Figueiredo Carvalho ${ }^{3}$, \\ Antônio Nazareno Guimarães Mendes ${ }^{4}$, Tiago Teruel Rezende ${ }^{5}$ João Paulo Felicori Carvalho ${ }^{6}$
}

(Received: December 20, 2016; accepted: Friday, June 30, 2017)

\begin{abstract}
The goal of our work was to evaluate physiological and agronomic traits, as well as the relationship between these traits in coffee cultivars coming from a germplasm supposedly resistant to leaf rust, and their response to framework pruning. The experiment was conducted at the Federal University of Lavras in randomized blocks with three replicates, with spacing of $3.5 \times 0.7 \mathrm{~m}$ and plots of 12 plants. An amount of 25 coffee cultivars was evaluated, from which 23 were considered resistant and two susceptible to leaf rust. Traits analyzed were the plagiotropic branch length and number of nodes, net photosynthetic rate, transpiration rate, water use efficiency, fluorescence and chlorophyll index, leaf area index, leaf rust incidence and yield. Catucai Amarelo 20/15 cv 479, Araponga MG1 and Tupi IAC 1669-33 cultivars show highly responsive to framework pruning. These cultivars have high yield associated to high net photosynthetic rate, water use efficiency and low transpiration rate. Moreover, the last two cultivars show a low incidence of leaf rust. The Acauã cultivar has a good response to framework pruning, showing high yield associated to lower incidence of leaf rust. Catucai Vermelho 785/15 cultivar is not responsive to framework pruning because show lower yield, high incidence of leaf rust, low vegetative growth and low water use efficiency.
\end{abstract}

Index terms: Coffea arabica L., Hemileia vastatrix, pruning.

\section{CARACTERIZAÇÃO DE CULTIVARES DE CAFEEIROS RESISTENTES À FERRUGEM SUBMETIDAS À PODA TIPO ESQUELETAMENTO}

RESUMO: Objetivou-se avaliar características fisiológicas e agronômicas, bem como a relação entre elas em cultivares de cafeeiros oriundos de germoplasma supostamente resistente à ferrugem e sua resposta à realização da poda tipo esqueletamento. O experimento foi instalado na Universidade Federal de Lavras, em blocos casualizados, com três repetições, no espaçamento de $3,5 \times 0,7 \mathrm{~m}$ e parcelas de 12 plantas. Avaliou-se 25 cultivares de cafeeiro, sendo 23 supostamente resistentes e 2 consideradas suscetíveis à ferrugem. Analisou-se comprimento de ramo plagiotrópico e número de nós; taxa fotossintética líquida; taxa transpiratória; eficiência de uso da água; fluorescência e índice de clorofila; índice de área foliar, incidência de ferrugem e produtividade. As cultivares Catucaí Amarelo 20/15 cv 479, Araponga MG1 e Tupi IAC 1669-33 mostram-se altamente responsivas à poda de esqueletamento por apresentarem alta produtividade aliada à alta taxa fotossintética, eficiência no uso da água e baixa taxa transpiratória. Além disso, as duas últimas cultivares apresentam baixa incidência de ferrugem. A cultivar Acauã apresenta boa resposta à realização dessa poda apresentando alta produtividade associada à menor incidência de ferrugem. A cultivar Catucaí Vermelho 785/15 não é responsiva à poda tipo esqueletamento, por apresentar menor produtividade, além de alta incidência de ferrugem, baixo crescimento vegetativo e baixa eficiência no uso da água.

Termos para indexação: Coffea arabica L., Hemileia vastatrix, poda.

\section{INTRODUCTION}

Although Brazil is the world's largest producer of coffee, it is known that the average crop yield is low (CAIXETA et al., 2008). One of the reasons for this is the presence of coffee rust (Hemileia vastatrix Berk. \& Br.), which is the main phytosanitary problem of the coffee plantation today, causing economic losses to coffee growers (BARBOSA; SOUZA; VIEIRA, 2010; BRITO et al., 2010; REZENDE et al., 2013). An alternative for the management of the disease is the use of resistant cultivars.
Leaf rust-resistant coffee plants have been shown as the best option for disease management (ZAMBOLIM; VALE, 2003). However, farmers and technicians have observed that leaf rustresistant coffee plants, despite having high yield in the first year, have reduced their vegetative vigor over the years, leading to yield loss.

Thus, the lack of scientific knowledge reinforces the need to perform studies related to the restoration of the productive capacity of these materials. The use of pruning, especially framework pruning is a viable technique for

\footnotetext{
${ }^{1,2,4}$ Federal University of Lavras/UFLA - Department of Agriculture/DAG - Cx. P. 3037 -37.200-000 - Lavras - MG estevamreis@outlook.com, tainah_f@hotmail.com,nazareno.ufla@hotmail.com

${ }^{3}$ Embrapa Café -Parque Estação Biológica/ Av. W3 Norte - Cx P 40.315 -70.770-90 - Brasília - DF - milene.carvalho@embrapa.br ${ }_{5}^{5}$ University José do Rosário Vellano/UNIFENAS - Institute of Agricultural Sciences/Faculty of Agronomy - Rodovia MG -179 Campus Universitário - 37.132-440 -Alfenas - MG - tiago.rezende@unifenas.br

${ }^{6}$ Foundation for Development of the Savanna of Minas Gerais/FUNDACCER - Alameda dos Babaçus, 738 - Morada Nova II - 38.748-690 - Patrocínio - MG - joao.paulo@cerradomineiro.org
}

Coffee Science, Lavras, v. 13, n. 1, p. 63 - 70, jan./mar. 2018 
recovering the vegetative vigor of these plants over the years.

Framework pruning is a technique that consists of the removal of a large terminal portion of all plagiotropic branches and is considered a relatively drastic operation because it reduces a large portion of shoot and consequently of root system (QUEIROZ-VOLTAN et al., 2006). Therefore, for the adequate application of this technique, it is necessary to associate the use of appropriated cultivars with a correct management in order to increase yield, in the short term, in relation to the free growth.

Therefore, the use of techniques to improve conventional selection methods of coffee plants is extremely important, favoring the identification of cultivars that are more productive and responsive to management practices, especially pruning usually employed in crop management.

It should also be considered that physiological studies have been highlighted as important ways for optimizing breeding studies (BATISTA et al., 2010). Moreover, agronomic traits associated with physiological methods allow identifying cultivars with favorable aspects to growth and development vegetative and productive.

Thus, the goal of our work was to evaluate physiological and agronomic traits, as well as the relationship between them in coffee trees cultivars originating from germplasm supposedly resistant to leaf rust and their response to framework pruning.

\section{MATERIAL AND METHODS}

The experiment was conducted at the Department of Agriculture, Federal University of Lavras, MG, Brazil, from August 2014 to July 2016.

Physiological and agronomic traits were evaluated in 25 Coffea arabica L. cultivars developed by the main genetic improvement programs in Brazil. The selected cultivars developed by PROCAFÉ with their respective source materials were: Catucaí Amarelo 2 SL (Icatu x Catuaí), Catucaí Amarelo 24/137 (Icatu x Catuaí), Catucaí Amarelo 20/15 cv. 479 (Icatu x Catuaí), Catucaí Vermelho 785/15 (Icatu x Catuaí), Catucaí Vermelho 20/15 cv. 476 (Icatu x Catuaí), Sabiá 398 (Catimor x Acaiá), Palma II (Catimor x Catuaí), Acauã (Sarchimor x Mundo Novo). The selected cultivars developed by EPAMIG were Oeiras MG 6851 (Caturra Vermelho (CIFC 19/1) x Timor Hybrid 832/1), Catiguá MG 1 (Catuaí Am. IAC 86 x Timor Hybrid 440-10), Sacramento MG 1 (Catuaí Verm. IAC 81 x Timor Hybrid 43852), Catiguá MG 2 (Catuaí Am. IAC 86 x Timor Hybrid 440-10), Araponga MG 1 (Catuaí Am. IAC 86 x Timor Hybrid 446/08), Paraíso MG 1 (Catuaí Am IAC 30 x Timor Hybrid 445-46), Pau Brasil MG 1 (Catuaí Verm. IAC 141 x Timor Hybrid 44234), Catiguá MG 3 (Catuaí Am. IAC 86 x Timor Hybrid 440-10) e Topázio MG 1190 (Mundo Novo x Catuaí). The selected IAC cultivars were Tupi IAC 1669-33 (Sarchimor), Obatã IAC 1669-20 (Sarchimor x Catuaí) e Catuai Vermelho IAC 144 (Mundo Novo x Caturra). Finally, the cultivars developed by IAPAR were Iapar 59 (Sarchimor 1669), IPR 98 (Sarchimor 1669 selection), IPR 99 (Catuaí x Icatu), IPR 103 (Catuaí x Icatu) and IPR 104 (Catuaí x Icatu).

From these cultivars, 23 were coming from a germplasm supposedly resistant to leaf rust (Hemileia vastatrix Berk. \& Br.) and two are susceptible commercial cultivars (Topázio $M G$ 1190 and Catuai Vermelho IAC 144), considered as control.

A randomized block design was used with three replicates and plots of 12 plants. Spacing was $3.5 \mathrm{~m}$ between rows $\mathrm{x} 0.70 \mathrm{~m}$ between plants.

Framework pruning was performed in September 2014. Posteriorly, the reduction of orthotropic stem was made at 2 meters of soil, with a single budding top at the terminal portion of plants.

To evaluate the physiological traits were used leaves in the third node from the apex of the branch, in the middle third of the plant. They were free from pest and disease attack, nutritional deficiencies and environmental stresses. The evaluations were performed nine months after framework pruning in June 2015, at the end of the vegetative period, beginning at 8 a.m. and ending at 11 a.m.

For the physiological analysis of gas exchanges, a portable infrared gas analyzer (IRGA LICOR - 6400XT) was used. The net photosynthetic rate $\left(\mathrm{A}-\mu \mathrm{mol} \mathrm{m} \mathrm{m}^{-2} \mathrm{~s}^{-1}\right)$ and the transpiration rate $\left(\mathrm{E}-\mu \mathrm{mol} \mathrm{m} \mathrm{m}^{-2} \mathrm{~s}^{-1}\right)$ were evaluated under artificial light $\left(1000 \mu \mathrm{mol} \mathrm{m}^{-2} \mathrm{~s}^{-1}\right)$. Water use efficiency (WUE) was calculated using the A/E ratio (SILVA et al., 2010).

Leaf area index (LAI) was determined according to the methodology proposed by Barbosa et al. (2012). 
The plagiotropic branch length $(\mathrm{cm})$ was evaluated in June 2015, at the end of the period of vegetative development and differentiation of buds for later production. An evaluation was performed using a graduated ruler by measuring three branches (lower, middle and upper third) on each side of the plant, with measures from the apex to the base of the branch developed after pruning, disregarding the first plagiotropic branch.

Leaf rust incidence was evaluated monthly through leaf sampling collected in the middle third of the third and fourth pairs of leaves from the plagiotropic branches, totaling 100 leaves per plot from December 2015 to March 2016. It was determined as a percentage, counting the number of leaves with sporulated pustules.

Harvesting was performed in the first production after framework pruning in all plants. It was made the measured in liters of harvested coffee and divided by the number of plants to obtain the average production (liters/plant). There was extrapolation (liters of coffee harvested/plot) and then conversion to $60 \mathrm{~kg}$ bags of processed coffee/ha through actual yield, calculated according to Moraes (2013) using a sample of four liters of coffee.

The statistical analyses were performed using the $\mathrm{R}$ software version 3.3.1(R CORE TEAM, 2016).

\section{RESULTS AND DISCUSSION}

For net photosynthetic rate (TABLE 1), the results showed superiority of the Catucai Amarelo 2 SL, Catucai Vermelho 20/15 cv. 476, Oeiras MG 6851, Catiguá MG 2, Paraíso MG 1 and Tupi IAC 1669-33 cultivars. Catucai Amarelo 24/137, Catucai Amarelo 20/15 cv. 479, Catucai Vermelho 785/15, Acauã, Sacramento MG 1, Araponga MG1, IPR 99, IPR 104, and Catuai Vermelho $I A C 144$ cultivars even though belonging to the second largest group of average photosynthetic rate, showed sufficient/high values for coffee trees, since these plants show low photosynthetic efficiency in relation to most woody plants (CANNELL, 1985).

The lowest transpiration rates were observed in Catucai Amarelo 2 SL, Catucai Amarelo 24/137, Catucai Amarelo 20/15 cv. 479, and Catucai Vermelho 20/15 cv. 476, Sabiá 398, Oeiras MG 6851, Catiguá MG 1, Araponga MG 1, Paraíso MG 1, Obatã IAC 1669-20, IPR 99, Topázio MG 1190 and Catuai Vermelho IAC 144 (TABLE 1). On the other hand, the highest averages were obtained by 'Acauã' and 'Catucai Vermelho 785/1' (TABLE 1). Transpiration is the loss of water vapor by plants, occurring mostly through the diffusion of water vapor through the stomata. In situations of water abundance, there is high water loss by transpiration, since water supply is constant, which is advantageous for the production of photoassimilates. However, when soil water is less abundant, the stomata will open less or remain closed to avoid plant dehydration (TAIZ; ZEIGER, 2013).

The plant efficiency in managing water loss while allowing sufficient $\mathrm{CO}_{2}$ absorption for photosynthesis can be determined by water use efficiency (WUE). The highest WUE values were obtained by Catucai Amarelo 24/137, Catucai Vermelho 20/15 cv. 476, Sabiá 398 and Topaz $M G 1190$ (TABLE 1). The WUE consists of the ratio between the net photosynthetic rate and the transpiration rate, i.e., plants with greater WUE produce more dry matter in relation to transpired water (RAMALHO et al., 2013). Carvalho et al. (2014) also observed that Catucai Amarelo 2 $S L$ cultivar showed high WUE due to its lower transpiration rate, resulting in a lower water loss in relation to the amount of dry matter produced.

Cultivars Catucai Amarelo 2 SL, Catucaí Amarelo 24/137, Catucai Amarelo 20/15 cv. 479, Catucai Vermelho 20/15 cv. 476, Oeiras MG 6851, Araponga MG1, Paraíso MG 1, IPR 99 and Catucai Vermelho 20/15 cv. 476 were in the two groups of cultivars with higher WUE. They were also in the two groups with higher net photosynthetic rate and in the group with lower transpiration rate in relation to others cultivars (TABLE 1). However, Sabiá 398, Catiguá MG 1 and Topázio MG 1190 showed high WUE mainly due to their low transpiration rate, despite having low net photosynthetic rates (TABLE 1). It is worth noting that Catucai Vermelho 785/15 and Acauã showed low WUE due to their high transpiration rates, despite obtaining high net photosynthetic rates. This is also true for Palma II, Pau Brasil MG1, Obatã IAC 1669-20, Iapar 59, IPR 98, IPR 103 and Catiguá $M G$ 3, but only because of the low net photosynthetic rates (TABLE 1).

Some cultivars showed higher leaf area indexes, for example, Catucai Amarelo $2 S L$, Catucai Amarelo 24/137, Catucaí Amarelo 20/15 cv. 479, Catucai Vermelho 20/15 cv. 476, Sabiá 398, Palma II, Catiguá MG 1, Paraíso MG 1, Pau Brasil MG 1, Obatã IAC 1669-20, IPR 99, IPR 103, IPR 104 and Topázio MG 1190 (TABLE 1). 
TABLE 1 - Averages of cultivars for the characteristics: net photosynthetic rate (A), transpiration rate $(E)$, water use efficiency (WUE), leaf area index (LAI), plagiotropic branch length (PBL), yield and leaf rust incidence (LRI) of 25 coffee cultivars after framework pruning in Lavras, MG, Brazil.

\begin{tabular}{|c|c|c|c|c|c|c|c|}
\hline Cultivar & A & $E$ & WUE & LAI & PBL & Yield & LRI \\
\hline Catucaí Amarelo $2 \mathrm{SL}$ & $10.71 \mathrm{a}$ & $0.96 \mathrm{~d}$ & $11.46 \mathrm{~b}$ & $4.09 \mathrm{a}$ & $49.17 \mathrm{a}$ & $72.30 \mathrm{~b}$ & $43.20 \mathrm{a}$ \\
\hline Catucaí Amarelo 24/137 & $8.85 \mathrm{~b}$ & $0.72 \mathrm{~d}$ & $12.64 \mathrm{a}$ & $4.34 \mathrm{a}$ & $54.33 \mathrm{a}$ & $67.43 \mathrm{~b}$ & $38.00 \mathrm{a}$ \\
\hline Catucaí Amarelo 20/15 cv 479 & $8.55 \mathrm{~b}$ & $0.78 \mathrm{~d}$ & $11.18 \mathrm{~b}$ & $4.56 \mathrm{a}$ & $43.33 \mathrm{~b}$ & $104.20 \mathrm{a}$ & $20.33 c$ \\
\hline Catucaí Vermelho 785/15 & $8.21 \mathrm{~b}$ & $2.41 \mathrm{~b}$ & $3.61 \mathrm{c}$ & $3.36 \mathrm{~b}$ & $35.67 \mathrm{~b}$ & $33.63 \mathrm{~d}$ & $32.40 \mathrm{~b}$ \\
\hline Catucaí Vermelho 20/15 cv 476 & $10.07 \mathrm{a}$ & $0.83 \mathrm{~d}$ & $12.41 \mathrm{a}$ & $4.59 \mathrm{a}$ & $52.33 \mathrm{a}$ & $49.87 \mathrm{c}$ & $42.13 \mathrm{a}$ \\
\hline Sabiá 398 & $7.10 \mathrm{c}$ & $0.56 \mathrm{~d}$ & $13.04 \mathrm{a}$ & $4.30 \mathrm{a}$ & $51.83 \mathrm{a}$ & $66.07 \mathrm{~b}$ & $21.40 \mathrm{c}$ \\
\hline Palma II & $5.57 \mathrm{c}$ & $1.58 \mathrm{c}$ & $3.69 \mathrm{c}$ & $4.33 \mathrm{a}$ & $44.00 \mathrm{~b}$ & $81.30 \mathrm{~b}$ & $0.73 \mathrm{~d}$ \\
\hline Acauã & $8.77 \mathrm{~b}$ & $3.37 \mathrm{a}$ & $2.95 \mathrm{c}$ & $3.99 \mathrm{~b}$ & $36.83 \mathrm{~b}$ & $93.43 \mathrm{a}$ & $3.07 \mathrm{~d}$ \\
\hline Oeiras MG 6851 & $9.88 \mathrm{a}$ & $1.06 \mathrm{~d}$ & $10.02 \mathrm{~b}$ & $3.92 \mathrm{~b}$ & $42.50 \mathrm{~b}$ & $69.93 \mathrm{~b}$ & $36.27 \mathrm{~b}$ \\
\hline Catiguá MG 1 & $6.96 \mathrm{c}$ & $0.82 \mathrm{~d}$ & $10.00 \mathrm{~b}$ & $4.16 \mathrm{a}$ & $45.50 \mathrm{a}$ & $68.60 \mathrm{~b}$ & $0.00 \mathrm{~d}$ \\
\hline Sacramento MG 1 & $8.74 \mathrm{~b}$ & $1.33 \mathrm{c}$ & $6.61 \mathrm{c}$ & $3.87 \mathrm{~b}$ & $47.50 \mathrm{a}$ & $46.70 \mathrm{c}$ & $0.67 \mathrm{~d}$ \\
\hline Catiguá MG 2 & $10.17 \mathrm{a}$ & $1.20 \mathrm{c}$ & $9.33 \mathrm{~b}$ & $3.93 \mathrm{~b}$ & $45.67 \mathrm{a}$ & $77.83 \mathrm{~b}$ & $0.00 \mathrm{~d}$ \\
\hline Araponga MG 1 & $8.35 \mathrm{~b}$ & $0.80 \mathrm{~d}$ & $10.54 \mathrm{~b}$ & $3.92 \mathrm{~b}$ & $40.33 \mathrm{~b}$ & $96.90 \mathrm{a}$ & $3.00 \mathrm{~d}$ \\
\hline Paraíso MG 1 & $9.86 \mathrm{a}$ & $0.94 \mathrm{~d}$ & $10.61 \mathrm{~b}$ & $4.07 \mathrm{a}$ & $42.33 \mathrm{~b}$ & $77.63 \mathrm{~b}$ & $0.13 \mathrm{~d}$ \\
\hline Pau Brasil MG 1 & $7.85 \mathrm{c}$ & $1.76 \mathrm{c}$ & $4.30 \mathrm{c}$ & $4.11 \mathrm{a}$ & $50.17 \mathrm{a}$ & $74.93 \mathrm{~b}$ & $0.00 \mathrm{~d}$ \\
\hline Tupi IAC 1669-33 & $10.45 \mathrm{a}$ & $1.26 \mathrm{c}$ & $8.60 \mathrm{~b}$ & $3.67 \mathrm{~b}$ & $41.83 \mathrm{~b}$ & $105.10 \mathrm{a}$ & $0.27 \mathrm{~d}$ \\
\hline Obatã IAC 1669-20 & $5.91 \mathrm{c}$ & $1.00 \mathrm{~d}$ & $5.99 \mathrm{c}$ & $4.19 \mathrm{a}$ & $41.17 \mathrm{~b}$ & $56.23 \mathrm{c}$ & $1.07 \mathrm{~d}$ \\
\hline Iapar 59 & $5.60 \mathrm{c}$ & $1.48 \mathrm{c}$ & $4.59 \mathrm{c}$ & $4.02 \mathrm{~b}$ & $31.67 \mathrm{~b}$ & $68.63 \mathrm{~b}$ & $0.00 \mathrm{~d}$ \\
\hline IPR 98 & $5.98 \mathrm{c}$ & $1.17 \mathrm{c}$ & $5.34 \mathrm{c}$ & $3.99 \mathrm{~b}$ & $39.00 \mathrm{~b}$ & $60.50 \mathrm{c}$ & $0.00 \mathrm{~d}$ \\
\hline IPR 99 & $8.05 \mathrm{~b}$ & $0.97 \mathrm{~d}$ & $8.97 \mathrm{~b}$ & $4.34 \mathrm{a}$ & $46.33 \mathrm{a}$ & $71.50 \mathrm{~b}$ & $0.00 \mathrm{~d}$ \\
\hline IPR 103 & $6.97 \mathrm{c}$ & $1.65 \mathrm{c}$ & $4.41 \mathrm{c}$ & $4.18 \mathrm{a}$ & $45.30 \mathrm{a}$ & $72.23 \mathrm{~b}$ & $32.00 \mathrm{~b}$ \\
\hline IPR 104 & $8.19 \mathrm{~b}$ & $1.86 \mathrm{c}$ & $4.80 \mathrm{c}$ & $4.38 \mathrm{a}$ & $45.33 \mathrm{a}$ & $78.93 \mathrm{~b}$ & $0.00 \mathrm{~d}$ \\
\hline Catiguá MG 3 & $4.77 \mathrm{c}$ & $1.17 \mathrm{c}$ & $4.19 \mathrm{c}$ & $3.76 \mathrm{~b}$ & $42.67 \mathrm{~b}$ & $55.73 \mathrm{c}$ & $0.00 \mathrm{~d}$ \\
\hline Topázio MG 1190 & $6.82 \mathrm{c}$ & $0.45 \mathrm{~d}$ & $15.79 \mathrm{a}$ & $4.22 \mathrm{a}$ & $38.33 \mathrm{~b}$ & $69.70 \mathrm{~b}$ & $39.47 \mathrm{a}$ \\
\hline Catucai Vermelho IAC 144 & $8.89 \mathrm{~b}$ & $0.84 \mathrm{~d}$ & $9.97 \mathrm{~b}$ & $3.66 \mathrm{~b}$ & $41.33 \mathrm{~b}$ & $46.73 \mathrm{c}$ & $41.33 \mathrm{a}$ \\
\hline
\end{tabular}

Means followed by the same letter in columns do not differ by the Scott-Knott test at 5\% probability.

According to Rezende et al. (2014), leaf area is related to yield crop. The estimated leaf area index is a central component of crop growth models, as well as for yield prediction (POCOCK; EVANS; MEMMOTT, 2010; WHITE et al., 2010). The results of our work corroborate partially with those found by these authors, since the cultivar Catucai Amarelo 20/15 cv. 479 showed higher leaf area index values and yield, showing that this parameter is a good indicator for predicting the yield of this cultivar. For the cultivars Catucai Amarelo 2 SL, Catucaí Amarelo 24/137, Catucai Vermelho 20/15 cv. 476, Sabiá 398, Catiguá MG 1, Pau Brasil MG 1, IPR 99, IPR 103 and IPR
104, the leaf area index was directly related to the growth of plagiotropic branches (TABLE 1).

Plagiotropic branch length was higher in the following cultivars: Catucai Amarelo 2 SL, Catucai Amarelo 24/137, and Catucai Vermelho 20/15 cv. 476, Sabiá 398, Catiguá MG 1, Sacramento MG 1, Catiguá MG 2, Pau Brasil MG 1, IPR 99, IPR 103 and IPR 104 (TABLE 1).

Carvalho et al. (2010) found that phenotypic traits such as number of plagiotropic branches, plant height and plagiotropic branch length showed high correlation with yield. These results do not corroborate with those observed in our work, once cultivars with great plagiotropic branch length 
showed low relationship with the highest yield observed (TABLE 1). This may occur because most of the cultivars with great plagiotropic branches had a higher leaf area index (TABLE 1), indicating an investment in vegetative growth in detriment to the reproductive growth.

For the variable yield (TABLE 1), four groups were designed. The ones with higher values for response to framework pruning were Tupi IAC 1669-33, Catucaí Amarelo 20/15 cv. 479, Araponga $M G 1$ and Acauã, with 105.10, 104.20, 96.20 and 93.43 bags.ha $^{-1}$, respectively. They were followed by Catucai Amarelo 2 SL, Catucai Amarelo24/137, Sabiá 398, Palma II, Oeiras MG 6851, Catiguá MG1, Catiguá MG2, Paraíso MG1, Pau Brasil MG1, Iapar 59, IPR 99, IPR 103, IPR 104 and Topázio MG 1190 cultivars, which also showed satisfactory yield (TABLE 1). It was found that some cultivars obtained little response to this pruning, with lower yield, such as: IPR 98, Obatã IAC 1669-20, Catiguá MG 3, Catucai Vermelho 20/15 cv. 476, Catuai Vermelho IAC 144, Sacramento MG 1 e Catucai Vermelho $785 / 15$, with yield of $60.50,56.23,55.73,49.87$, $46.73,46.70$, and 33.63 bags.ha $^{-1}$, respectively (TABLE 1).

The performance of certain cultivars after framework pruning was already evaluated in some studies. Carvalho et al. (2013) observed a satisfactory response to this pruning in progenies derived from the cross between Mundo Novo and Catuaí. Silva et al. (2016) analyzed the recovery capacity of four and a half years old coffee cultivars after framework pruning and verified that the Sabiá 398, Topázio MG1190 and Catiguá MG3 highlighted in the first biennium after pruning.

Carbon availability from the photosynthetic process for plant growth can be increased due to increasing photosynthesis depending on nutrient availability and the growth capacity of each species (KIRSCHBAUM, 2011). Photoassimilates produced along this process can be mainly redirected to the growth of reproductive organs such as beans (DING et al., 2007), resulting in higher yield and/or directed to vegetative organs such as leaves, stems and roots (COVRE et al. 2016), reflecting higher vegetative growth.

A different behavior of redirecting photoassimilates was observed in the cultivars that showed high net photosynthetic rates (TABLE 1). According to Covre et al. (2016), the reproductive growth of Coffea canephora limited the vegetative growth. The results found in the present work corroborate with this assertion for cultivars with the largest yield, 'Acauã', 'Araponga MG 1' and 'Tupi IAC 1669-33', which showed lower vegetative growth, with small plagiotropic branch length and leaf area index in relation to others cultivars. Thus, it can be suggested that these cultivars may be a good option for the zero-crop system, in which cultivars are pruned again after harvesting, since they would possibly exhibit low yields in the following year due to their low vegetative growth.

The cultivar Catuai Amarelo 20/15 cv. 479, which belongs to the group with higher yield, also obtained higher average values for leaf area index (TABLE 1). Therefore, this cultivar can be a good cultivar for management in which a programmed pruning system or pruning in longer cycles is used due to high vegetative growth combined with yield.

The cultivars that showed lower yield were: Catucai Vermelho 785/15, Catucai Vermelho 20/15 cv. 476, Sacramento MG1, Obatã 166920, IPR 98, Catiguá MG 3 and Catuaí Vermelho IAC 144 (TABLE 1). When was compared the net photosynthetic rate (A) with vegetative growth (PBL and LAI) and yield, it was found that, for these cultivars, targeting of photoassimilates may have predominated for vegetative organs. This is true, for example, for Catucai Vermelho 20/15 cv. 476, Sacramento MG1 and Obatã 1669-20. In addition, the photoassimilates production may have be insufficient for vegetative growth and a satisfactory yield, which is the case of Catucai Vermelho 785/15, IPR 98, Catiguá MG 3 and Catuai Vermelho IAC 144 cultivars.

Campostrini and Maestri (1998) performed studies comparing photosynthesis and yield of five coffee genotypes (C. canephora), observed that all genotypes showed the same photosynthetic efficiency, but obtained different yield levels, showing that the difference between these two variables may not be correlated.

Carvalho et al. (2012) found that, among leaf rust-resistant coffee plants, the Catucai Vermelho 785/15 cultivar showed yield below $44.9 \%$ in relation to the average of four crops from superior cultivars in the studied sites, and were not pruned. Such research corroborates with the results obtained in the present work, being that this cultivar showed a decreased yield of $66 \%$ in relation to the average of the group from superior cultivars after the first production after pruning. 
For the leaf rust incidence (\%), four groups were formed. Catucai Amarelo 2SL (43.20\%), Catucaí Amarelo 24/137 (38.00\%), and Catucai Vermelho 20/15 cv. $476 \quad(42.13 \%)$ showed incidence equal to the susceptible patterns Topázio MG 1190 (39.47\%) and Catuaí Vermelho IAC 144 $(41.33 \%)$ (TABLE 1), evidencing the breakdown of their resistance by physiological races of fungi prevalent in the region.

Other cultivars, also considered as leaf rustresistant, although not resembling the susceptible patterns, showed high disease incidence: Catucai Vermelho 785/15 (32.40\%), Oeiras MG 6851 (36.27\%), IPR 103 (32.00\%), Sabiá 398 (21.40\%) and Catucai Amarelo 20/15 cv. 479 (20.33\%) (TABLE 1).

Cultivars from the Catuai group, carrying only the SH 5 gene, are susceptible to the disease (SHIGUEOKA et al., 2014). Thus, some resistance gene of Catucai ("Icatu" x "Catuaí") cultivars, different from SH 5, was completely broken by some $H$. vastratrix race (SERA et al., 2010).

There are also reports of the occurrence of resistance breakdown by new races in cultivars previously considered as leaf rustresistant, including those originated from Catimor germplasm (VARZEA et al., 2002). Carvalho (2011) verified that the Oeiras MG 6851 cultivar, released as leaf rust-resistant, show high susceptible to the disease, in addition to high deterioration and lower vegetative vigor.

Plants from the 'Hibrido de Timor' have at least the major genes SH 5 to $\mathrm{SH} 9$ (BETTENCOURT; LOPES; PALMA, 1992). Besides these ones already identified, it is likely that other genes will be present in these genotypes (VARZEA; MARQUES, 2005), conferring greater resistance to the materials coming from this crossbreed.

Observing the relationship between leaf rust-incidence and yield in coffee can be suggested that even cultivars that showed high or low disease incidence obtained different yields (TABLE 1). This fact can be explained due the fact that most part of studied materials showed leaf rustresistance genes. Therefore, the leaf rust-incidence (fungal sporulation) may have occurred when the fruits already showed satisfactory fruiting filling, not influencing the leaf area index that could compromise the photoassimilates production that would be directed to fruit development. The high disease incidence affects mainly the production of the following year, since the loss of leaves decreases photoassimilates production and consequently the yield. This fact was verified in the present work, in which the annual yield was not compromised.

\section{CONCLUSIONS}

Cultivars such as Catucai Amarelo 20/15 cv. 479, Araponga MG1 and Tupi IAC 166933 are highly responsive to framework pruning because they show high yield associated to high net photosynthetic rate and low transpiration rate. Moreover, the last two cultivars have a low leaf rust-incidence. The Acauã cultivar shows a good response to this pruning, showing high yield associated to the lower leaf rust-incidence.

Catucai Vermelho 785/15 cultivar is not responsive to framework pruning showing lower yield, besides high leaf rust-incidence and low vegetative growth.

\section{ACKNOWLEDGEMENTS}

The authors would like to thank the Coordination for the Improvement of Higher Education Personnel (CAPES), the National Council for Scientific and Technological Development (CNPq), the Foundation for Supporting Research of the State of Minas Gerais (FAPEMIG) and Consórcio Pesquisa Café for financial support.

\section{REFERENCES}

BARBOSA, D. H. S. G.; SOUZA, R. M.; VIEIRA, H. D. Field assessment of coffee (Coffea arabica L.) cultivars in Meloidogyne exigua-infested or-free fields in Rio de Janeiro State, Brazil. Crop Protection, Guildford, v. 29, n. 2, p. 175-177, Feb. 2010.

BARBOSA, J. P. R. A. D. et al. Estimativa do IAF de cafeeiro a partir do volume de folhas e arquitetura da planta. Coffee Science, Lavras, v. 7, n. 3, p. 267-274, set./dez. 2012.

BATISTA, L. A. et al. Anatomia foliar e potencial hídrico na tolerância de cultivares de café ao estresse hídrico. Revista Ciência Agronômica, Fortaleza, v. 41, n. 3, p. 475-481, jul./set. 2010.

BETTENCOURT, A. J.; LOPES, J.; PALMA, S. Fatores genéticos que condicionam a resistência às raças de Hemileia vastatrix Berk. et $\mathrm{Br}$. dos clones-tipo dos grupos 1, 2 e 3 de derivados de Híbrido de Timor. Brotéria Genética, Oeiras, v. 13, n. 80, p. 185-194, 1992.

BRITO, G. G. et al. Inheritance of coffee leaf rust resistance and identification of AFLP markers linked to the resistance gene. Euphytica, Wageningen, v. 173, n. 2, p. 255-264, May 2010. 
CAIXETA, G. Z. T. et al. Gerenciamento como forma de garantir a competitividade da cafeicultura. Informe Agropecuário, Belo Horizonte, v. 29, n. 247, p. 14-23, nov./dez. 2008.

CAMPOSTRINI, E; MAESTRI, M. Photosynthetic potential of five genotypes of Coffea canephora Pierre. Revista Brasileira de Fisiologia Vegetal, Londrina, v. 10, n. 1, p. 13-18, jan./mar. 1998.

CANNELL, M. G. R. Physiology of coffee crop. In: CLIFFORD, M. N.; WILLSON, K. C. (Ed.). Coffee: botany, biochemistry and production of beans and beverage. London: Croom Helm, 1985. p. 108-134.

CARVALHO, A. M. de. Desempenho agronômico de cultivares de cafeeiros resistentes a ferrugem. 2011. 89 p. Tese (Doutorado em Fitotecnia)-Universidade Federal de Lavras, Lavras, 2011.

CARVAlHO, A. M. de et al. Correlação entre crescimento e produtividade de cultivares de café em diferentes regiões de Minas Gerais, Brasil. Pesquisa Agropecuária Brasileira, Brasília, DF, v. 45, n. 3, p. 269-275, mar. 2010.

- Desempenho agronômico de cultivares de café resistentes à ferrugem no Estado de Minas Gerais, Brasil. Bragantia, Campinas, v. 71, n. 4, p. 481-487, dez. 2012.

CARVALHO, F. P. et al. Water use efficiency by coffee arabica after glyphosate application. Acta Scientiarum Agronomy, Maringá, v. 36, n. 3, p. 373-377, jul./set. 2014.

CARVALHO, G. R. et al. Comportamento de progênies F4 de cafeeiros arábica, antes e após a poda tipo esqueletamento. Coffee Science, Lavras, v. 8, n. 1, p. 33-42, jan./mar. 2013.

CROVE, A. M. et al. Vegetative growth of Conilon coffee plants under two water conditions in the Atlantic region of Bahia State, Brazil. Acta Scientiarum Agronomy, Maringá, v. 38, n. 4, p. 535-545, out./dez. 2016.

DING, L. et al. Phothosynthetic rate and yield formation in different maize hybrids. Biologia Plantarum, Prague, v. 51, n. 1, p. 165-168, Jan. 2007.

KIRSCHBAUM, M. U. F. Does enhanced photosynthesis enhance growth?: lessons learned from $\mathrm{CO}_{2}$ enrichment studies. Plant Physiology, Brentwood, v. 155, n. 1, p. 117-124, Jan. 2011.
MORAES, B. F. X. de. Tamanho de parcela e de amostra na avaliação de produtividade de grãos de café arábica. 2013. 97 p. Dissertação (Mestrado em Genética e Melhoramento de Plantas)-Universidade Federal de Lavras, Lavras, 2013.

POCOCK, M. J.; EVANS, D. M.; MEMMOTT, J. The impact of farm management on species-specific leaf area index (LAI): farm-scale data and predictive models. Agriculture, Ecosystems \& Environment, Amsterdam, v. 135, n. 4, p. 279-287, Feb. 2010.

QUEIROZ-VOLTAN, R. B. et al. Eficiência da poda em cafeeiros no controle da Xylella fastidiosa. Bragantia, Campinas, v. 65, n. 3, p. 433-440, jul./set. 2006.

R CORE TEAM. R: a language and environment for statistical computing. Vienna: R Foundation for Statistical Computing, 2016. 3501 p. Disponível em: <http://www.R-project.org>. Acesso em: 8 ago. 2016.

RAMALHO, J. C. et al. Sustained photosynthetic performance of Coffea spp. under long-term enhanced $\left[\mathrm{CO}_{2}\right]$. PLoS One, San Francisco, v. 8, n. 12, 2013. Available from: <http://journals.plos.org/plosone/ article?id=10.1371/journal.pone.0082712>. Acesso em: 8 ago. 2016.

REZENDE, F. et al. Índice de área foliar, densidade de plantio e manejo de irrigação do cafeeiro. Coffee Science, Lavras, v. 9, n. 3, p. 374-384, set./dez. 2014.

REZENDE, R. M. et al. Resistance of Coffea arabica progenies in field conditions infested by Meloidogyne exigua. Nematropica, Bradenton, v. 43, n. 2, p. 233240, Dec. 2013.

SERA, G. H. et al. Resistência à ferrugem alaranjada em cultivares de café. Coffee Science, Lavras, v. 5, p. 59-66, jan./abr. 2010.

SHIGUEOKA, L. H. et al. Selection of Arabic coffee progenies with rust resistance. Crop Breeding and Applied Biotechnology, Viçosa, v. 14, n. 2, p. 88-93, abr./jun. 2014.

SILVA, V. A. et al. Recuperação de cultivares de café submetidas ao esqueletamento aos quatro anos e meio de idade. Coffee Science, Lavras, v. 11, n. 1, p. 55-64, jan./mar. 2016.

Resposta fisiológica de clone de café Conilon sensível à deficiência hídrica enxertado em portaenxerto tolerante. Pesquisa Agropecuária Brasileira, Brasília, DF, v. 45, n. 5, p. 457-464, maio 2010. 
TAIZ, L.; ZEIGER, E. Fisiologia vegetal. 5. ed. Porto Alegre: Artmed, 2013. 954 p.

VARZEA, V. M. P. et al. Resistência do cafeeiro a Hemileia vastatrix. In: ZAMBOLIM, L. (Ed.). O estado da arte de tecnologias na produção de café. 4. ed. Viçosa, MG: Ed. UFV, 2002. p. 297-320.

VARZEA, V. M. P.; MARQUES, D. V. Population variability of Hemileia vastatrix vs. coffee durable resistance. In: ZAMBOLIM, L.; ZAMBOLIM, E. M.;
VÁRZEA, V. M. P. (Ed.). Durable resistance to coffee leaf rust. Viçosa, MG: Ed. UFV, 2005. p. 53-74.

WHITE, D. et al. Observed and modified leaf area index in Eucalyptus globulus plantations: test of optimality and equilibrium hypotheses. Tree Physiology, Oxford, v. 30, n. 7, p. 831-844, 2010.

ZAMBOLIM, L.; VALE, F. X. R. Estratégias múltiplas no manejo integrado de doenças do cafeeiro. Fitopatologia Brasileira, Brasília, DF, v. 28, n. 1, p. 137-153, jan./fev. 2003. 